\title{
ECONOMIC ACTIVITY OF RESIDENTS IN BORDER DISTRICTS OF POLAND: A STUDY OF NON-AGRICULTURAL BUSINESS ENTERPRISES
}

\begin{abstract}
This article aims to evaluate the economic activity of residents living in Polish border districts. Economic activity is measured via non-agricultural business activity development, with particular focus on financial support received from the European Union (EU). The spatial scope of the research covers Polish border districts, and the temporal scope includes the years 2004-2017 and 2007-2013. Empirical data were obtained from the Local Data Bank of the Main Statistical Office in Warsaw. We conducted comparative analyses, using dynamics indicator and coefficients of variation. Results of our analyses suggest that the level and dynamics of non-agricultural business activity development after Poland's integration with EU are similar in the border districts as compared with all Polish districts. The most dynamic development was observed in the western border districts, whereas the least dynamic growth and the lowest level is observed along the eastern border. Residents of the border districts are less active in raising EU funds to develop non-agricultural businesses in comparison with Polish districts as a whole.
\end{abstract}

Keywords: economic activity of residents, non-agricultural business activity, Poland's border districts.

\section{INTRODUCTION}

Non-agricultural business activities play a significant role in the economy stimulating social and economic development of a particular region. They are regarded the source of its residents' wealth and contribute to each economy's prosperity, including the local economy (Sawicka, 2000; Honjo, Harada, 2006).

High quality of living standard of local communities, provided by means of social and economic development, is believed to be the mission of a non-agricultural business activity. The mission's success guarantees further development of a labour market, diversification of household income and improvement in technical and social infrastructure. Non-agricultural business activities should also utilise social and economic specificity as

\footnotetext{
${ }^{1}$ Dariusz Zając, DSc, PhD, Eng, Associate Prof., Institute of Economics and Finance, University of Rzeszow, ul. M. Ćwiklińskiej 2, 35-601 Rzeszów, Poland; e-mail: dzajac@ur.edu.pl. ORCID: 0000-0001-7918-1366.

2 Magdalena D. Suraj, MSc, Institute of Economics and Finance, University of Rzeszow, ul. M. Ćwiklińskiej 2, 35-601 Rzeszów, Poland; e-mail: msuraj@ur.edu.pl. ORCID: 0000-0003-4061-1853 (corresponding author).
} 
well as the natural environment characteristics of a particular region (e.g. district area) which will contribute to the development of its functional diversity (Bański, 2016).

Supporting the development of non-agricultural business activities is the subject of particular attention and an interest of the majority of countries, including the highly developed ones that pursue an active economic policy in this aspect. This clearly concerns also the European Union and Poland (Wasilewski, 2014; Mickiewicz, Mickiewicz, 2016).

Thus, a significant factor enhancing the development of a non-agricultural business sector is the financial backing received from the European Union within the confines of various programmes and projects, including PROW. It should be noted that rural businesses benefited significantly from the European Union funds (financial transfers), which helped to intensify the process of numerous enterprises' growth (Kłodziński, 2016).

What is more, the development of a non-agricultural business enterprise is substantially determined by its spatial location and characteristics of a local environment (e.g. district) (Zając, 2014). For this reason border location of a business may also play a vital role. Micro enterprises often see their own chances to survive on the market in growth, productivity and profitability improvement, and other conditions or adjustments of microeconomic, that is local, character (Musiał, Barczyk, Zukovskis, 2018).

The aim of the article is to demonstrate and evaluate economic activity of residents living in Polish border districts in terms of non-agricultural business activity development with particular attention paid to financial support from the European Union (as exemplified by PROW 2007-2013).

Spatial scope of the research covers Polish border districts (excluding towns serving as districts), divided into three groups, i.e. neighbouring western, southern and eastern borders; the timeframe accounts for 2004-2017 and 2007-2013 (PROW).

\section{RESEARCH PROBLEM IN LITERATURE REVIEW AND THEORY OF ECONOMICS}

The issues of non-agricultural business, entrepreneur and their institutional character (that is a business enterprise), is deeply grounded in the theory of economics as well as in business practice. Developed countries experienced as they are, most often serve as a medium of progress, initiative, creative approach and innovation (Schumpeter, 1960; Drucker, 1992; Gruszecki, 1994; Sawicka, 2000; Gąsiorowska-Mącznik, 2017).

Spatial economics provides the theories of traditional economics with spatial aspects regarding land management. Economic and social environment concentrates human activity on a particular area (subject of spatial economics). If economic and social environment is organised spatially, then land management includes its elements location as well as their mutual relations with natural environment. From economic point of view land management should deliver proper (optimal) location solutions in processes of urbanisation, industrialisation, communication network location, tourist facilities and economic entities with respect to markets' and infrastructure facilities' location (Domański, 2006; Siekierski, 2008).

Location theory focuses on explaining spatial organisation, it deals with an in-depth analysis of general economic issues of location and its underlying aim is the choice of location for a business enterprise. The theory elaborates on factors determining location and competitiveness of a business enterprise that hold utmost importance in terms of a labour market, employment and migration processes influencing social and economic development 
of a particular area (Toepel, 1997; Głąbicka, Grewiński, 2005; Kopaczewska, 2008, Musiał, 2009). One shall note that the primary development objective is the quality of life improvement of its residents, namely the social welfare (Woźniak, 2018). It is interesting that along with technical advances, transformation process development, international integration and globalisation, the access to particular resources ceases to be a key criterion in search of business enterprise location. Instead, other criteria gain significance, such as availability and quality of producing input, technology, innovations, cooperation opportunities, institutional facilities (quality of local authorities, business support institutions) and living conditions (e.g. security, quality of education, healthcare and recreation services) (Gilowska, Gorzelak, Jałowiecki, 1999; Adamowicz, 2008). Considering the issues of business enterprise location in space one shall not forget the no-tion of a geographical rent. It serves as a special bonus received in exchange for geographical location of a business enterprise in certain geopolitical system including also neighbouring interactions. It combines the concepts of the Thünen's land rent related to location of a business (e.g. a production site) dependent on transportation costs and the Wieser's urban rent regarding economic activity of particular area residents (Kopaczewska, 2008, Musiał, 2009).

The notion of a border region is ambiguous and each region of this type is unique. Nonetheless, it can be defined as a part of geographical area characterised by its location along national border. What matters most in the case of border region's operating is the geopolitical environment resulting from its location, relations with neighbouring countries and consequently defining the specificity and roles of a national border. The border's spatial and functional volatility influences various social, cultural and economic processes occurring in neighbouring areas (Anderson, O’Dowd, 1999; Miszczuk, 2013).

The process of the European Union integration was accompanied by the cooperation of cross-border regions. International, regional and local levels of integration contributed to lowering an existing spatial barrier, which the state border actually had been, to the extent that it became literary unnoticeable. A unique example of the latter is the Schengen Zone's functioning (Miszczuk, 2013). It is worth mentioning that, according to scientific research, geographical neighbouring encourages building business relations and cooperation supporting processes of innovation (Cassi, Plunket, 2014; Davids, Frenken, 2018; Jespersen et al. 2018).

According to expert literature border regions can be divided into: isolated regions being the effect of closed border, coexisting regions - with limited mutual impact, cooperating regions - integrated ones with stable relations whose establishment is possible within geopolitical regions (Martinez, 1999).

\section{RESEARCH METHOGOLOGY}

Empirical data used in the article has been obtained from the Local Data Bank (BDL) of the Polish Main Statistical Office in Warsaw. Collected and organised data has been prepared in the form of tables. The elaboration employs the method of comparative analysis, namely the temporal and spatial comparisons, with the use of a dynamics indicator as well as coefficients of variation of analysed phenomena. 


\section{DEVELOPMENT OF NON-AGRICULTURAL BUSINESS ACTIVITY IN BORDER DISTRICTS IN POLAND}

Border districts in Poland (excluding towns serving as districts) include 52 units in total, which constitutes $16.6 \%$ of total number of districts in the country. The largest number of districts can be found in the group alongside the western border; the other two groups of districts, namely the ones neighbouring the eastern and southern national border are of comparable sizes (Table 1). The development level of non-agricultural business activity of particular area residents (e.g. a district) may be represented with the number of business enterprises per 1,000 residents in working age.

The data included in Table 1 allow the conclusion that the level and dynamics of nonagricultural business activity development after Poland's accession to the European Union, i.e. in the period 2004-2017, are similar for border districts in Poland and the districts in Poland as a whole. The features' diversification among districts is not very significant, especially as far as the dynamics of non-agricultural business activity is concerned, and refers to both border districts and the districts in Poland as a whole.

Table 1. Number of business enterprises per 1,000 residents in working age and its changes in border districts in Poland in 2004-2017

\begin{tabular}{|c|c|c|c|}
\hline \multirow{2}{*}{ Details } & \multicolumn{2}{|c|}{ Years } & \multirow{2}{*}{$\begin{array}{c}\text { Changes in } \\
\text { 2004-2017 (dynamics, } \\
\text { year 2004=100) }\end{array}$} \\
\hline & 2004 & 2017 & \\
\hline \multicolumn{4}{|c|}{ Districts in Poland in total (excluding towns serving as districts) $\mathrm{N}=314$} \\
\hline Average & 121.5 & 142.6 & 117.8 \\
\hline Coefficient of variation V (\%) & 23.7 & 24.9 & 10.1 \\
\hline \multicolumn{4}{|c|}{ Border districts in Poland in total (excluding towns serving as districts) $\mathrm{N}=52$} \\
\hline Average & 119.0 & 140.9 & 119.0 \\
\hline Coefficient of variation V $(\%)$ & 26.3 & 28.6 & 11.9 \\
\hline \multicolumn{4}{|c|}{ Districts neighbouring western border (excluding towns serving as districts) $\mathrm{N}=8$} \\
\hline Average & 146.3 & 173.7 & 119.3 \\
\hline Coefficient of variation V $(\%)$ & 11.7 & 13.1 & 11.3 \\
\hline \multicolumn{4}{|c|}{ Districts neighbouring southern border (excluding towns serving as districts) $\mathrm{N}=23$} \\
\hline Average & 128.4 & 156.8 & 122.7 \\
\hline Coefficient of variation V $(\%)$ & 24.9 & 27.2 & 12.8 \\
\hline \multicolumn{4}{|c|}{ Districts neighbouring eastern border (excluding towns serving as districts) $\mathrm{N}=21$} \\
\hline Average & 98.1 & 111.1 & 114.8 \\
\hline Coefficient of variation V $(\%)$ & 20.9 & 15.7 & 10.2 \\
\hline
\end{tabular}

Source: Own elaboration based on empirical data from the Local Data Bank, Polish Main Statistical Office in Warsaw.

However, border districts in Poland differ significantly according to the level and dynamics of development of non-agricultural business activity. Clearly, the highest level of this kind of activity development can be noted in the group of districts neighbouring the western border. Next, the districts located alongside the southern border accounted for the highest dynamics in the development of non-agricultural business activity after Poland's integra-tion with the European Union, namely in the period 2004-2017. The opposite can 
be observed in the eastern border districts. They are characterised by the lowest level and dynamics of non-agricultural business activity development. Last but not least, the features' diversification among border districts in all of the three groups is not very significant (Table 1).

\section{ECONOMIC ACTIVITY OF BORDER DISTRICT RESIDENTS IN POLAND REGARDING THE EUROPEAN UNION FUND RAISING TO DEVELOP NON-AGRICULTURAL BUSINESS ACTIVITY (AS EXEMPLIFIED BY PROW 2007-2013)}

Taking into account the total value of financial funds obtained from the European Union within the confines of PROW 2007-2013 - Action: Diver-sification towards nonagricultural activity and the number of the programme beneficiaries as indicators of economic activity of residents in bor-der districts, one shall note that their activity is smaller if compared to the districts in Poland as a whole. The features' diversification among particular districts is relatively huge and concerns not only the border districts but also the districts in Poland as a whole. On the other hand, considering the average value of gained funds per beneficiary it is interesting to note that in the group of border districts the value is lower than in the group of Polish districts as a whole and, additionally, its diversification among districts is in-significant (Table 2).

Table 2. Number of payments and value of the European Union funds within PROW 2007-2013 - Action: Diversification towards non-agricultural activity in border districts in Poland

\begin{tabular}{|l|c|c|c|}
\hline \multicolumn{1}{|c|}{ Details } & Funds paid (in PLN) & $\begin{array}{c}\text { Number of } \\
\text { payments }\end{array}$ & $\begin{array}{c}\text { Value of funds per } \\
\text { payment (in PLN) }\end{array}$ \\
\hline Districts in Poland in total (excluding towns serving as districts) N=314 \\
\hline Average & 3286312.7 & 48.7 & 65709.6 \\
\hline Coefficient of variation V (\%) & 90.6 & 86.8 & 11.2 \\
\hline Border districts in Poland in total (excluding towns serving as districts) N=52 \\
\hline Average & 2190735.8 & 33.9 & 63143.6 \\
\hline Coefficient of variation V (\%) & 84.1 & 82.8 & 14.7 \\
\hline Districts neighbouring western border (excluding towns serving as districts) N=8 \\
\hline Average & 1281940.8 & 18.5 & 68165.5 \\
\hline Coefficient of variation V (\%) & 94.5 & 92.8 & 6.4 \\
\hline Districts neighbouring southern border (excluding towns serving as districts) N=23 \\
\hline \multicolumn{5}{|c|}{ Average } & 1515191.5 & 24.5 & 59961.4 \\
\hline Coefficient of variation V (\%) & 82.4 & 82.5 & 18.9 \\
\hline Districts neighbouring eastern border (excluding towns serving as districts) N=21 \\
\hline Average & 3276825.3 & 50.2 & 64715.8 \\
\hline Coefficient of variation V (\%) & 63.5 & 62.6 & 10.6 \\
\hline
\end{tabular}

Source: Own elaboration based on empirical data from the Local Data Bank, Polish Main Statistical Office in Warsaw.

However, the border regions in Poland tend to be very diversified in terms of their residents' economic activity as far as gaining funds within PROW 2007-2013 - Action: Diversification towards non-agricultural activity is concerned. It is unquestionable that 
residents of districts neighbouring the eastern border were the most active and both the total amount of funds received as well as the number of beneficiaries granted were the highest and comparable with the average of all districts in the country. On the contrary, the least economic activity was identified among residents of districts neighbouring the western national border followed by residents of the southern border districts. Diversification of analysed features (i.e. the total amount of funds received and the number of beneficiaries) among particular districts in all groups of border districts is very meaningful, especially in the group of districts neighbouring the western national border. In turns, considering the average value of funds per beneficiary one shall note that it is definitely the highest in the group of western border districts, whereas the lowest - in the group of southern border districts. Simultaneously, in the group of eastern border districts the average value of funds received per beneficiary resembles most the average of all Polish districts in this aspect. Finally, the feature's diversification among particular districts in the group of border districts is minor, especially in the case of the group of districts neighbouring the western national border (Table 2).

Taking into account the total amount of sources granted by the European Union within PROW 2007-2013 - Action: Diversification towards non-agricultural activity and the number of beneficiaries, as indicators of economic activity of residents of border districts in Poland in this aspect one shall note less activity in comparison with the activity of all Polish districts' residents. The features' diversification among particular districts is substantial and concerns not only the border districts but also Polish districts as a whole. The average value of gained funds per beneficiary is lower in the group of border districts if compared to average of Polish districts as a whole and, additionally, the feature's diversification among particular districts is minor (Table 3).

Table 3. Number of payments and value of the European Union funds within PROW 2007-2013 -Action: Creation and development of micro enterprises in border districts in Poland

\begin{tabular}{|l|c|c|c|}
\hline Details & $\begin{array}{l}\text { Funds paid } \\
\text { (in PLN) }\end{array}$ & $\begin{array}{l}\text { Number of } \\
\text { payments }\end{array}$ & $\begin{array}{l}\text { Value of funds per } \\
\text { payment (in PLN) }\end{array}$ \\
\hline Districts in Poland in total (excluding towns serving as districts) N=314 \\
\hline Average & 6262288.1 & 43.5 & 143159.5 \\
\hline Coefficient of variation V (\%) & 81.2 & 81.1 & 12.5 \\
\hline Border districts in Poland in total (excluding towns serving as districts) N=52 \\
\hline Average & 6059400.5 & 42.9 & 140959.4 \\
\hline Coefficient of variation V (\%) & 87.7 & 88.6 & 14.8 \\
\hline Districts neighbouring western border (excluding towns serving as districts) N=8 \\
\hline Average & 4032006.4 & 27.5 & 142155.4 \\
\hline Coefficient of variation V (\%) & 76.7 & 67.5 & 15.1 \\
\hline Districts neighbouring southern border (excluding towns serving as districts) N=23 \\
\hline Average & 7105826.5 & 51.7 & 135738.9 \\
\hline Coefficient of variation V (\%) & 95.9 & 94.8 & 9.7 \\
\hline Districts neighbouring eastern border (excluding towns serving as districts) N=21 \\
\hline Average & 5685655.6 & 39.2 & 146221.4 \\
\hline Coefficient of variation V (\%) & 67.1 & 69.1 & 18.0 \\
\hline
\end{tabular}

Source: Own elaboration based on empirical data from the Local Data Bank, Polish Main Statistical Office in Warsaw. 
Nonetheless, the border districts in Poland seem to be very diversified as far as the economic activity of their residents is concerned in terms of funds gaining within PROW 2007-2013 - Action: Creation and development of micro enterprises. Residents of the southern border districts are clearly most active - the total amount of funds received and the number of benefi-ciaries granted are the highest and higher than average for all Polish districts. The least active residents in this aspect, however, are the ones in the western border districts. In the group of the eastern border districts the total amount of funds and number of beneficiaries are closest to the average values of Polish districts as a whole. The features' diversification in the groups of border districts is very meaningful, particularly in the group of the southern border districts. Taking into account the average value of raised funds per beneficiary one shall note that it is clearly higher in the group of districts located alongside the eastern border of Poland, and the lowest - in the group of the southern border districts. In the case of western border districts, the average value of sources per beneficiary is more alike the average obtained by Polish districts as a whole. Last but not least, the feature diversification among particular districts is insignificant in all of the border district groups, in particular in the case of the southern border district group (Table 3).

\section{CONCLUSIONS}

1. Border districts in Poland represent a small share of total number of districts in the country; the group of the western border districts is the least numerous.

2. The level and dynamics of non-agricultural business activity development after Poland's integration with the European Union, are similar in the border districts and the Polish districts as a whole. However, the border districts are very diversified, as far as this aspect is concerned.

3. Neighbouring developed country such as Germany for the border districts in Poland constitutes a significant factor enhancing business relations of their residents and, simultaneously, the development of non-agricultural business activity in the districts. Similar trend can be noticed with respect to the districts in the proximity of the Czech Republic and Slovakia. On the contrary, the group of the eastern border districts in Po-land represents the lowest level and dynamics of development in the field of non-agricultural business activity after Poland's integration with the European Union. This, somehow, constitutes a barrier to further social and economic development of the Polish region, especially considering the region's cohesion with the remaining part of the country.

4. The border districts' residents are less active, if we analyse raising the EU funds devoted to non-agricultural business activity in comparison with residents of Polish districts as a whole. Polish border districts are, however, very diversified in this aspect.

5. Despite the great involvement of the eastern border districts' residents in raising the EU funds within PROW 2007-2013 - Action: Diversification towards non-agricultural activity, both level and dynamics of non-agricultural business activity development are relatively low.

6. The great involvement of the southern border districts' residents in raising the EU funds within PROW 2007-2013 - Action: Creation and development of micro enterprises resulted in significant dynamics of non-agricultural business activity development in the region after Poland's integration with the European Union. 


\section{REFERENCES}

Adamowicz, M. (2008). Konkurencyjność jednostek terytorialnych w skali lokalnej. „,Roczniki Naukowe SERiA”. T. X. Zeszyt 2.

Anderson, J., O’Dowd, L. (1999). Borders, Border Regions and Territoriality: Contradictory Meanings. "Changing Significance. Regional Studies" Vol. 33, No. 7. DOI: 10.1080/ 00343409950078648.

Bański, J. (2016). Rozwój przedsiębiorczości na terenach wiejskich - diagnoza $i$ wyzwania. „Studia KPZK PAN” nr 167.

Cassi, L., Plunket, A. (2014). Proximity, network formation and inventive performance: in search of the proximity paradox. "The Annals of Regional Science" Vol. 53, Issue 2. DOI: 10.1007/s00168-014-0612-6.

Davids, M., Frenken, K. (2018). Proximity, knowledge base and the innovation process: towards an integrated framework. "Regional Studies" Vol. 52, Issue 1. DOI: 10.1080/00343404. 2017.1287349.

Domański, R. (2006). Gospodarka przestrzenna. Podstawy teoretyczne. Warszawa: PWN. Drucker, P.F. (1992). Innowacja i przedsiębiorczość. Praktyka i zasady. Warszawa: PWE.

Feher, A., Goşa, V., Hurmuzache, T., Raicov, M. (2014). The Development of Rural Entrepreneurship in Romania. "Review on Agriculture and Rural Development" Vol. 3 (1).

Gąsiorowska-Mącznik, E. (2017). Teoretyczne podstawy przedsiębiorczości. „Nierówności Społeczne a Wzrost Gospodarczy” nr 52(4/2017). DOI: 10.15584/nsawg.2017.4.28.

Gilowska, Z., Gorzelak, G., Jałowiecki, B. (1999). Kontrakt dla Ściany Wschodniej. Warszawa: Municipiun S.A.

Głąbicka, K., Grewiński, M. (2005). Polityka spójności społeczno-gospodarczej Unii Europejskiej. Warszawa: Dom Wydawniczy ELIPSA.

Gruszecki, T. (1994). Przedsiębiorca w teorii ekonomii. Warszawa: Wydawnictwo „Cedor”.

Haggblade, S., Hazell, P., Reardon, T. (2010). The Rural Non-farm Economy: Prospects for Growth and Poverty Reduction. "World Development" Vol. 38, No. 10. DOI: 10.1016/j. worlddev.2009.06.008.

Honjo, Y., Harada, N. (2006). SME Policy, Financial Structure and Firm Growth: Evidence from Japan. "Small Business Economics" Vol. 27, Issue 4-5. DOI: 10.1007/s11187-005-6703-0.

Jespersen, K., Rigamonti, D., Jensen, M., Bysted, R. (2018). Analysis of SMEs partner proximity preferences for process innovation. "Small Business Economics" Vol. 51, Issue 4. DOI: 10.1007/s11187-017-9969-0.

Kisiel, R., Jarzębowicz, N. (2017) Non-Agricultural Business Activity in the Olecko District. “J. Agribus. Rural Dev.” No. 4(46). DOI: 10.17306/J.JARD.2017.00374.

Kłodziński, M. (2016). Bariery rozwoju obszarów wiejskich ze szczególnym uwzględnieniem sektora małej i średniej przedsiębiorczości. „Studia KPZK PAN” nr 167.

Kopaczewska, K. (2008). Renta geograficzna a rozwój społeczno-gospodarczy. Warszawa: Wydawnictwo CeDeWu.

Martinez, O.J. (1999). The Dynamics of Border Interaction. New Approaches to Border Analysis [In:] Schofield, C.H., ed., Global Boundaries. „World Boundaries” Vol. 1. London-New York: Routledge.

Mickiewicz, A., Mickiewicz, B. (2016). Pozarolnicza działalność gospodarcza na obszarach wiejskich w Polsce. „Roczniki Naukowe SERiA”. T. XVIII. Zeszyt 1. 
Miszczuk, A. (2013). Uwarunkowania peryferyjności regionu przygranicznego. Lublin: Norbertinum.

Musiał, W. (2009). Demograficzne $i$ społeczne uwarunkowania powstawania wiejskich obszarów problemowych. „Acta Scientiarum Polonorum, Oeconomia” nr 8(2).

Musiał, W., Barczyk, J., Zukovskis, J. (2018). Bariery i szanse rozwoju drobnej przedsiębiorczości na obszarach wiejskich w Polsce i na Litwie w ocenach ekonomistów. „Zeszyty Naukowe Wydziału Nauk Ekonomicznych Politechniki Koszalińskiej” nr 22.

Sawicka, J. (2000). Założenie i prowadzenie matego przedsiębiorstwa. Warszawa: SGGW.

Schumpeter, J.A. (1960). Teoria rozwoju gospodarczego. Warszawa: PWN.

Siekierski, J. (2008). Ład przestrzenny $i$ lokalizacja $w$ teorii ekonomii a konkurencyjność regionów. „Roczniki Naukowe SERiA”. T. X. Zeszyt 2.

Toepel, K. (1997). Zusammenwirken von nationaler und europäischer Regionalpolitik in den neuen Bundesländern. Frankfurt am Main.

Turok I. (2010). Cities, Regions and Competitiveness. “Journal of Regional Studies” Vol. 38, 2004. Issue 9. DOI: 10.1080/0034340042000292647.

Wasilewski, A., ed. (2014). Efektywność instrumentów polityki regionalnej i strukturalnej wspierających rozwój pozarolniczej działalności gospodarczej na obszarach wiejskich. Raport Programu Wieloletniego 2011-2014 „Konkurencyjność polskiej gospodarki żywnościowej $w$ warunkach globalizacji i integracji europejskiej” nr 108. Warszawa: IERiGŻ-PIB.

Woźniak, M.G. (2018). Nowa ekonomia strukturalna $w$ kontekście rozwoju zintegrowanego. „Nierówności Społeczne a Wzrost Gospodarczy” nr 54(2/2018). DOI: 10.15584/nsawg. 2018.2.3.

Zając, D. (2014). Znaczenie pozarolniczej działalności gospodarczej rolników w procesie rozwoju wielofunkcyjności rolnictwa $i$ obszarów wiejskich. „Prace Naukowe Wydziatu Ekonomii Uniwersytetu Rzeszowskiego, Seria: Monografie i Opracowania” nr 17. Rzeszów: Wydawnictwo UR.

DOI: $10.7862 /$ rz.2020.hss.10

The text was submitted to the editorial office: November 2019.

The text was accepted for publication: March 2020. 
